\title{
Framework for articulating instructional practices and conceptions
}

\author{
Melissa Dancy \\ University of North Carolina at Charlotte, Charlotte, North Carolina 28223, USA \\ Charles Henderson \\ Western Michigan University, Kalamazoo, Michigan, 49008, USA
}

(Received 25 August 2006; published 15 May 2007)

\begin{abstract}
We present and describe the development of a framework for assessing or categorizing instructional practices and related conceptions in the context of introductory physics instruction. The purpose of the framework is for articulating practices and conceptions of individual instructors or of curricula. It was developed based on the research literature and interviews with physics faculty and contains ideas with widespread acceptance as well as some outside mainstream rhetoric. We provide an example of how this framework can be applied by using it to categorize aspects of three well-known research-based curricula. The results of this categorization highlight areas that are common in research-based curricular designs and other areas that are less embraced but worthy of consideration.
\end{abstract}

DOI: 10.1103/PhysRevSTPER.3.010103

\section{INTRODUCTION}

As McDermott and Redish allude in the introduction of their landmark resource letter, at the heart of all education research is the goal of "improvement."

This resource letter is meant to contribute to the establishment of a research base that can serve as a resource for ongoing improvement and enrichment of student learning in physics (Ref. 1, p. 755).

After all, if one were of the opinion that the state of education was as it should be, then there would be no need to put effort into better understanding of how, when, or why students learn. The physics education research community has developed around this goal of improving physics education and believes that such improvement is possible. This goal is often more generally referred to as "reforming" physics instruction.

Although the idea of reforming physics instruction drives the field, rarely do we articulate exactly what is meant by reform. What does reformed instruction look like? What does it mean to improve? What changes are desired? Is it increased understanding of specific topics, ${ }^{2}$ increased success at problem solving, ${ }^{3}$ improved attitudes and beliefs about science, ${ }^{4}$ more physics majors, ${ }^{5}$ the building of community bridges, ${ }^{6}$ or perhaps improved confidence in one's ability to critique and use science? ${ }^{7}$

While words such as reform, improvement, and change are frequently used in the dialogue of the community, they are often not clearly defined, as if the physics education research (PER) community agreed on their meaning. The failure of the PER community to clearly articulate and discuss its beliefs, goals, recommended practices, and values can lead to misunderstandings and difficulties in the interactions among community members.

For example, a curriculum developer who views improvement as preparing more individuals to participate in the global economy would likely develop different curricula and ask different research questions than someone who views improvement as making physics more personally relevant to students. They may both embrace the use of cooperative
PACS number(s): 01.40.Fk, 01.30.lb, 01.40.gb, 01.40.J-

learning, for example, but would likely implement it differently. In their conversations with each other, their unstated differences in values would likely lead to discontinuities in interactions.

In addition to talking with one another, curriculum developers must communicate effectively with non-PER faculty. If curriculum developers do not clearly articulate their goals, objectives, theoretical commitments, and resulting methods, this communication can fail. For example, faculty may not see the value of peer-peer interaction that is an important component of interactivity in some PER-based reforms, such as peer instruction, ${ }^{8}$ and is based on the theoretical perspective of social-cognitive educational theories. ${ }^{9}$ Thus these instructors may attempt to implement reforms without this critical piece, ${ }^{10}$ which would likely limit the effectiveness of the implementation.

There is nearly unanimous agreement that instruction can improve and many proposed ideas for how to accomplish this improvement. However, the specifics remain largely unarticulated and assumptions abound about what constitutes reformed instruction as well as the underlying goals and rationale for reform. In this paper we begin a discussion of these ill-articulated assumptions by presenting a theoretical framework for characterizing and discussing practices and beliefs associated with both traditional and research-based instruction. We briefly describe the framework and its development. We then provide an extended example of the use of the framework as an analysis tool for viewing three representative curricula developed within the field of physics education research. We do not intend for the framework presented here to be the last word on the categorization of the conceptions and practices of individuals or curricula. Rather we see this as an important first step in developing a tool to help in the articulation of these conceptions and practices.

\section{DEVELOPMENT OF FRAMEWORK OF INSTRUCTIONAL PRACTICES AND CONCEPTIONS TO CHARACTERIZE TRADITIONAL AND ALTERNATIVE INSTRUCTION}

As we began work on a project to understand the practices and conceptions of physics faculty, ${ }^{11,12}$ we quickly realized 
TABLE I. Interactivity category of the practices framework (P1).

\begin{tabular}{cc}
\hline \hline Practices consistent with traditional instruction & Practices consistent with alternative instruction \\
\hline $\begin{array}{c}\text { Minimal degree of interactivity } \\
\text { Teacher does most of the talking. Few students } \\
\text { talk (lecture) }\end{array}$ & $\begin{array}{c}\text { Significant degree of interactivity } \\
\text { Students and teacher share talking. Most } \\
\text { students talk (conversation) } \\
\text { Most discourse is teacher-student } \\
\begin{array}{c}\text { Significant student-student discourse } \\
\text { ask clarifying questions and teacher asks rhetorical } \\
\text { and/or closed questions) }\end{array} \\
\begin{array}{c}\text { Discourse focuses on students' ideas (e.g., } \\
\text { Students write teacher's ideas (i.e., take notes) } \\
\text { Students are physically passive }\end{array} \\
\text { and teacher ask and answer conceptual } \\
\text { Students write their own ideas }\end{array}$ \\
\hline \hline
\end{tabular}

that there is no clear agreement about what constitutes reformed instruction and that articulating the extent of reform for a particular instructor or even a particular classroom was not an easy task. Much of the dialogue surrounding educational change is ill-defined. We therefore developed a framework of educational practices and conceptions in order to explicitly document the extent of alternative and traditional practices and conceptions of an instructor. While other frameworks, especially for instructional practices, are available in the literature (e.g., Refs. 13-22), and we did incorporate ideas from these frameworks in our own work, we found that none of them were sufficiently detailed and inclusive. Such instruments are often focused on a specific vision of "good" instruction (e.g., "inquiry"18 or "constructivist instruction"13), rather than including a wide range of possible instructional practices. In addition, they tend to focus on actions that can be observed in a single class period, which can miss important aspects of instruction (e.g., grading practices, assessment items used, course design).

\section{A. Practices}

The framework was developed through an iterative process. We began by cataloging and clearly articulating alternative ideas that have been proposed either within the PER community or within the larger educational research community. As stated above, some of these ideas came from existing frameworks, while others were based on our knowledge of the literature and discourses in the field. For example, education research communities generally promote interactive engagement. ${ }^{23}$ Hence the first general dimension in the practices section of the framework refers to the degree of interactivity. Traditional instructional practices are typically characterized by minimal interactivity while alternative instructional practices are typically characterized by significant interactivity. ${ }^{23}$

However, we found it was not sufficient to place "significant interactivity" on the alternative practices side of the framework because this term is vague and used with varying meanings. For example, even within PER, interactivity is used to refer to teacher-student interactions, ${ }^{24}$ student-student interactions, ${ }^{25}$ student-artifact interactions, ${ }^{26,27}$ or studenttechnology interactions. ${ }^{28,29}$ We needed to clearly articulate the various and specific ways in which the term is used. In addition we further clarified the meaning of each practice by placing it in contrast to a traditional practice. For example, the practice of "significant student-student discourse" is in contrast to the traditional practice of primarily teacherstudent discourse.

Table I illustrates the details of the interactivity category of the framework and Table II presents all the main categories of the practices dimensions. The full practices section of the framework is given in Appendix A. Note that references are provided for the alternative practices. These are not intended to provide complete documentation for each idea, but rather a suggested starting point for those interested in reading more about a particular practice.

\section{B. Conceptions}

Likewise, we developed a framework for categorizing conceptions consistent with traditional or alternative practices. Although conceptions are less tangible than practice, and therefore problematic to measure, it is worthwhile to understand and document not just what people do, but also why they do it.

There are many ways that researchers have classified aspects of teachers' cognitions. ${ }^{39-41}$ We use the term conception. This term is used quite broadly to describe any mental construct of an individual teacher that potentially provides a rationale for a particular instructional practice. Thus consistent with other researchers ${ }^{39}$ we do not attempt to distinguish between beliefs, attitudes, goals, and other similar mental constructs. These are all referred to as conceptions.

Although it may appear on the surface that a particular instructional conception would lead to a particular instructional action, most researchers have failed to document such a relationship. ${ }^{39,40,42,43}$ One reason for this apparent discrepancy is that teachers' underlying conceptual frameworks are very complicated and often have inconsistencies. ${ }^{39,40,44-47}$ In addition, circumstances or factors external to an individual teacher are also known to have an influence on instructional decisions. ${ }^{12,48-50}$ To illustrate the potentially complicated relationship between conceptions and practices, we will consider a different context. Surveys show that almost all Americans hold the conception that smoking is detrimental to 
TABLE II. Main categories of practices.

\begin{tabular}{|c|c|c|}
\hline & $\begin{array}{l}\text { Practices consistent with } \\
\text { traditional instruction }\end{array}$ & $\begin{array}{l}\text { Practices consistent with } \\
\text { alternative instruction }\end{array}$ \\
\hline P1. Interactivity & One-sided discourse, passive students & Conversation, active students (Ref. 23) \\
\hline P2. Instructional decisions & Decisions made by teacher & $\begin{array}{l}\text { Decisions shared by teacher and students } \\
\text { (Ref. 30) }\end{array}$ \\
\hline P3. Knowledge source & Students receive expert knowledge & Students develop own knowledge (Ref. 31) \\
\hline P4. Student success & Success measured against preset standards & $\begin{array}{l}\text { Success measured by individual improvement } \\
\text { (Ref. 32) }\end{array}$ \\
\hline P5. Learning mode & Competitive or individualistic learning modes & Cooperative learning modes (Ref. 33) \\
\hline P6. Motivation & External motivators & Internal motivators (Ref. 34) \\
\hline P7. Assessment & Knowledge-based assessment & Process-based assessment (Ref. 35) \\
\hline P8. Content & $\begin{array}{l}\text { Explicitly teach only physics facts } \\
\text { and principles }\end{array}$ & $\begin{array}{c}\text { Explicitly teach learning, thinking, and problem } \\
\text { solving skills in addition to physics content } \\
\text { (Ref. 36) }\end{array}$ \\
\hline P9. Instructional design & $\begin{array}{l}\text { Knowledge-driven instruction based on } \\
\text { understanding of the structure of physics }\end{array}$ & $\begin{array}{l}\text { Student-driven instruction based on } \\
\text { understanding of student learning within the } \\
\text { discipline of physics (Ref. 32) }\end{array}$ \\
\hline P10. Problem solving & $\begin{array}{l}\text { Formulaic problem solving: Problems assigned } \\
\text { to students are well-defined and similar to } \\
\text { problems students have previously seen }\end{array}$ & $\begin{array}{l}\text { Creative problem solving: Problems assigned to } \\
\text { students are novel to solver and may have } \\
\text { unknown or open-ended solutions (Refs. } 37,38 \text { ) }\end{array}$ \\
\hline
\end{tabular}

health. ${ }^{51}$ Yet, some people with this conception avoid smoking while others do not. A smoker might agree that smoking is unhealthy (negative outcome) but also believes smoking will attract friends (positive outcome) and so choose to smoke despite a conception that would predict another action. ${ }^{52}$ Likewise some people might smoke despite a conception that their health is at risk because it is encouraged by their surroundings (advertising, role models, physical addiction, etc.)..$^{53}$

Having stated that the relationship between conceptions and actions is unpredictable and that conceptions are often inconsistent, we assert that consideration of conceptions is still worthwhile. Conceptions have been shown to be instrumental in defining tasks and selecting cognitive tools with which to interpret, plan, and make decisions regarding such tasks; hence they play a critical role in defining behavior and organizing knowledge and information. ${ }^{45,47,54}$ Thus while conceptions may not consistently predict action, they are not unrelated to action. To continue with the smoker example, a smoker with the conception that smoking is unhealthy may one day be motivated to change this behavior when other circumstances also change. Thus conceptions can add insight to behavior and also suggest strategies that may be successful in changing behavior.

We include conceptions in the framework that are theoretically connected to practice. Often these conceptions can be found in the literature that promotes a particular alternative practice. However, it is important to note that we do not assume that these conceptions and practices are correlated with one another in real instructional situations. For example, there is a logical link between having a constructivist view of knowledge acquisition and supporting an interactive learning environment. Likewise, an instructor holding transmissionist conceptions about knowledge acquisition might be expected to utilize practices associated with low levels of interactivity as described above. However, we do not claim that just because there is a logical link between a particular practice and conception that any particular conception actually leads to a particular practice-as noted earlier, other research has shown that there can be a great deal of inconsistency between an instructor's stated conceptions and their actual practice. In fact, when using the framework to categorize the conceptions and practices of five physics faculty we found many such inconsistencies. These inconsistencies often appear to be related to situational constraints the faculty encountered (such as a requirement to cover content) and are discussed in another paper. ${ }^{12}$

Similar to the organization of practices, we organized the conceptions section of the framework under general categories, followed by specific supporting examples to clarify the description. Table III presents the main categories of conceptions. As with the practices, references are provided for those interested in reading further about a particular alternative view. The full conceptions section of the framework is provided in Appendix B.

Again, although we organize the conceptions around "traditional" and "alternative" we make no claim that the conceptions on the traditional side are conceptions held by traditional instructors. We only claim that conceptions on the traditional side are logically consistent with traditional practice. In other words, if you start with a conception on the traditional side and ask, "What kind of instruction would one expect from an instructor who strongly holds this conception and has few environmental constraints?" the answer would be mostly on the traditional side of practice, likewise for the conceptions on the alternative side.

For example, if an instructor held an extreme positivist view (C3) of knowledges he or she would view knowledge 
TABLE III. Main categories of conceptions.

\begin{tabular}{|c|c|c|}
\hline & $\begin{array}{l}\text { Conceptions consistent with } \\
\text { traditional instruction }\end{array}$ & $\begin{array}{l}\text { Conceptions consistent with } \\
\text { alternative instruction }\end{array}$ \\
\hline $\mathrm{C} 1$. Learning view & Transmissionist & Constructivist (Ref. 55) \\
\hline C2. Expertise & $\begin{array}{c}\text { Involves the accumulation of factual } \\
\text { information }\end{array}$ & $\begin{array}{l}\text { Involves qualitative changes in } \\
\text { thinking (Ref. 55) }\end{array}$ \\
\hline C3. Knowledge view & Positivist: knowledge is absolute & $\begin{array}{l}\text { Post-positivist: knowledge is } \\
\text { socially constructed (Ref. 56) }\end{array}$ \\
\hline C4. Nature of physics & A quantitative discipline & $\begin{array}{l}\text { A quantitative and qualitative } \\
\text { discipline (Ref. 57) }\end{array}$ \\
\hline C5. Role of school & $\begin{array}{l}\text { Sort and certify students for roles in } \\
\text { the workplace and society }\end{array}$ & $\begin{array}{l}\text { Develop independent thinkers and } \\
\text { enrich students' personal lives (Ref. 58) }\end{array}$ \\
\hline C6. Students & $\begin{array}{c}\text { All students learn the same way and } \\
\text { only some are capable of learning } \\
\text { physics }\end{array}$ & $\begin{array}{c}\text { Different students learn differently, } \\
\text { but all are capable of learning } \\
\text { physics (Ref. 59) }\end{array}$ \\
\hline C7. Teacher role & Teacher should teach & Teacher should guide (Ref. 32) \\
\hline C8. Diversity & Students should adapt to the teacher & $\begin{array}{l}\text { Teacher should adapt to the students } \\
\text { (Ref. 60) }\end{array}$ \\
\hline C9. Desired outcomes & $\begin{array}{l}\text { Students can quickly and accurately } \\
\text { solve familiar problems within the } \\
\text { context of physics }\end{array}$ & $\begin{array}{l}\text { Students develop an understanding } \\
\text { of physics concepts as well as the } \\
\text { skills to apply these concepts to new } \\
\text { situations (Ref. 61) }\end{array}$ \\
\hline C10. Scientific literacy & $\begin{array}{l}\text { Informed citizen who can appreciate } \\
\text { scientific methods and use science } \\
\text { as developed by scientists in everyday } \\
\text { and professional decision making }\end{array}$ & $\begin{array}{l}\text { Informed citizen who can apply } \\
\text { scientific methods to problems that } \\
\text { interest them as well as critique } \\
\text { science methods and results (Ref. } 7 \text { ) }\end{array}$ \\
\hline
\end{tabular}

as objective, knowable, and separate from human thought. Instruction based on a positivist view of knowledge would (i) be content focused (in order to pass on the objective knowledge), (ii) be teacher centered (since the teacher is the expert about the knowledge), (iii) be focused on certification and credentialing (need to document that students have learned the knowledge), and (iv) place no particular emphasis on social interaction in the classroom (it is not particularly important since knowledge is separate from human thought). These actions are all consistent with a transmission approach to knowledge development and all fall on the traditional side of the practices framework.

Likewise if an instructor held an extreme post-positivist (C3) view of knowledge he or she would view knowledge as dynamic and socially constructed. Instruction based on a post-positivist view of knowledge would (i) be process focused (to learn knowledge development), (ii) include social interaction in class (since knowledge is developed through social interactions), (iii) involve the teacher acting as a facilitator (rather than a source of knowledge), and (iv) follow a constructivist approach to knowledge development. These actions are all on the alternative side of the practices framework.

We do not claim that any instructor actually holds these extreme views; in our experience most instructors hold views consistent with both positivism and post-positivism. We offer these designations not as positivistic representations of reality but rather as post-positivistic theoretical constructs to frame and entice discussion.

Once we had a draft framework, we used interview data to test, refine, and expand the framework. These interviews, with five tenured physics faculty from four different institutions (one small liberal arts college, two regional universities, and one major research university) who teach introductory level physics courses, were collected as part of a project to better understand instructors' experiences with educational change and are reported in more detail elsewhere. ${ }^{11,12}$ The interviews were semistructured, exploratory interviews containing questions about instructional goals, current and past instructional practices, attempts to change practices, and familiarity with educational research.

The interview transcripts were carefully read for all instances of identifiable practices or conceptions of the interviewee. When a practice or conception was identified it was coded according to the framework. If the practice or conception did not fit well within the current framework, then the framework was revised or expanded to accommodate the new practice or conception. In this way, new dimensions emerged and old ones were described in better detail. Overall, we found that the initial framework was able to account for most practices and conceptions of our interviewees. Throughout this process, one or both authors independently performed the analysis which was then verified by the other.

Therefore our final framework is the result of both theory and experiment. It is based primarily in the research literature and informed by both our own personal notions of important practices and conceptions as well as use in the analysis of instructor interviews.

\section{Comments on the framework}

The framework is not intended to be a continuum on which an individual can be located. Although it is set up with 
contrasting practices and conceptions, there is no evidence or reason to believe that an individual will fall on one side or the other. In fact, it is common for individuals to exhibit behaviors and conceptions on both sides. For example, an instructor may lecture while teaching some topics yet use highly interactive techniques for other topics. Likewise, the same instructor could treat learning as primarily an individual activity in one situation but in another situation treat learning as a social activity. ${ }^{62}$

We present the framework as a distinction between traditional ideas and alternative ideas. We do no intend to pass judgment on the various practices and conceptions, nor do we propose any "ideal" location on the framework. While all of the ideas presented on the alternative side of the framework are there because there is some reason to believe they are worthwhile (for example, most have been empirically shown to increase student learning, at least in some context) we do not mean to propose that all traditional ideas are bad all of the time, nor that the alternative ideas are always superior. For example, while it is well established that lecturing is an ineffective way to develop conceptual understanding, it may be effective in some circumstances, such as when the goal is to transmit factual information. ${ }^{63}$ Our goal is to present a range of ideas and a framework by which individuals or curriculum can be understood.

In addition, the framework includes many alternative ideas that are uncommon even in most "reformed" curricula. It was our intention to include a wide array of research-based alternatives, not just those commonly found in the reform discourse. This allows the framework to be useful not just for describing individual instructors but also for describing the extent to which whole curricula, approaches, and even research communities deviate from traditional practice. For example, using the framework, we can consider what kinds of reforms are strongly promoted by the PER community and what kinds of reforms are not strongly supported. This type of analysis is useful for framing the field in a broader context as well as identifying potentially productive new lines of inquiry.

\section{USING THE FRAMEWORK TO VIEW ESTABLISHED CURRICULA IN PER}

In a separate paper, we show that the framework can be a useful tool to examine the conceptions and practices of individual instructors. ${ }^{12}$ In the remainder of this paper, we demonstrate how the framework can be used to examine the conceptions and practices embodied in specific curricula. In viewing PER curricula through the framework, we find many alternative practices and conceptions embraced to a large extent while other alternative practices and conceptions are embraced only weakly within the PER community. Using the framework to articulate trends in PER curricula can help us to better understand the current PER movement and suggest possibly fruitful future directions. Since PER is a diverse and complex field we will attempt to make the discussion more concrete by focusing on three established curricula designed to be used in introductory level physics courses. These three approaches were chosen because they are widely known and respected, proven successful, well documented and disseminated, and represent a broad range of the products of mainstream PER. These approaches are described briefly below.

Washington Tutorials. ${ }^{64,65}$ In the tutorial approach, the recitation often associated with large lecture courses is replaced with tutorial sessions in which students work cooperatively on carefully structured worksheets designed to address common misconceptions and build conceptual understanding. Students typically participate in tutorial sessions after covering the given topic in a more traditional lecture setting.

Interactive Lecture Demonstrations (ILD's). ${ }^{66}$ In an ILD activity, some lecture time is set aside for microcomputerbased demonstrations of concepts. In these demonstrations students are shown the setup, asked to make predictions as individuals about the outcome of the demonstration to be performed, and then discuss their predictions in small groups before being shown the demonstration. Students are then asked to describe the result and discuss again in small groups.

Workshop Physics. ${ }^{67,68}$ In Workshop Physics, there are no formal lectures. All course activities take place in an integrated laboratory environment where students are free to explore concepts with real equipment and work at their own pace. An activity guide structures the students' hands-on explorations and concept development. Students are explicitly encouraged to talk to one another and to collaborate on course activities. The instructor and the written activity guide serve to direct and facilitate student work and discussions.

In the analysis that follows we take each of these approaches and locate it within the framework for two practice dimensions (P1: interactivity and $\mathrm{P} 2$ : instructional decisions) and one conception dimension (C1: learning view). We chose to discuss the practice of interactivity and conception of learning views because these are often discussed in the PER community and it is often assumed that the PER community and curricula are in strong agreement on the alternative side of these issues. We chose to discuss the practice of student input into instructional decisions because there is very little discussion about this in the PER community. For each dimension analyzed we used published materials to document and justify our placement in the framework.

It is important to note that categorizations do not necessarily represent the people who developed the various approaches but rather the practices and implicit or explicit conceptions expressed in the curricular materials. This becomes particularly important to note when considering the conception's dimensions. Just as an individual instructor's actions are influenced by a complex and, perhaps conflicting, set of conceptions interacting with their perception of their instructional situation, ${ }^{12,62}$ it is reasonable to assume that the practices embodied in a curriculum represent some mix of the developers' conceptions and the constraints from the institutions and traditions in which they work. For example, a developer may fully embrace constructivism yet design a curriculum to be used in conjunction with some component of transmission-based lecturing because of situational constraints such as large class sizes. In this case we would consider the curriculum to represent a mix of traditional and alternative conceptions even though the developers, if asked, 
TABLE IV. Summary of three PER-based instructional approaches along three categories of the framework.

\begin{tabular}{|c|c|c|c|}
\hline & Washington Tutorials & Interactive Lecture Demos & Workshop Physics \\
\hline Interactivity (P1) & $\begin{array}{l}\text { Although the Washington } \\
\text { Tutorials promote a highly } \\
\text { interactive environment during } \\
\text { the actual tutorial sessions, these } \\
\text { sessions only comprise one } \\
\text { component of the overall course. } \\
\text { Since the tutorials were designed, } \\
\text { and assumed to be used as a } \\
\text { supplement to a traditional } \\
\text { lecture-based course, much of the } \\
\text { course experience is still likely } \\
\text { passive for the students. Therefore } \\
\text { we rate the tutorials as being mixed } \\
\text { within the interactivity category. }\end{array}$ & $\begin{array}{l}\text { As with the tutorials, ILD's are } \\
\text { designed to be used in conjunction } \\
\text { with a traditional, passive lecture. } \\
\text { Therefore it is assumed that most } \\
\text { of the course is traditional and } \\
\text { passive. Although the ILD's } \\
\text { integrate some interactivity even } \\
\text { during the ILD activity the } \\
\text { instructor is still largely leading } \\
\text { discussion and performing activities } \\
\text { with only minimal discussion } \\
\text { among students. Therefore we rate } \\
\text { ILD's as being semitraditional within } \\
\text { the interactivity category. }\end{array}$ & $\begin{array}{l}\text { Workshop Physics was } \\
\text { designed to be a fully } \\
\text { interactive learning } \\
\text { environment and incorporates } \\
\text { all aspects of interactivity. } \\
\text { Therefore we rate workshop } \\
\text { physics as alternative } \\
\text { within the interactivity } \\
\text { category. }\end{array}$ \\
\hline Learning view $(\mathrm{C} 1)$ & $\begin{array}{l}\text { The developers of the } \\
\text { Washington Tutorials express } \\
\text { strong conceptions consistent } \\
\text { with a constructivist view of } \\
\text { knowledge development. } \\
\text { However, the explicit structure of } \\
\text { the tutorials indicates some } \\
\text { transmissionist philosophy. } \\
\text { Additionally, the tutorials are } \\
\text { placed after traditional } \\
\text { (presumably transmissionist) } \\
\text { lectures on the same material. } \\
\text { Therefore we rate the tutorials as } \\
\text { being semialternative } \\
\text { within the learning view } \\
\text { category. }\end{array}$ & $\begin{array}{l}\text { While the developers of the ILD's } \\
\text { do clearly express constructivist } \\
\text { conceptions, the ILD's are } \\
\text { embedded in an otherwise } \\
\text { traditional lecture which is assumed } \\
\text { to be grounded in transmission } \\
\text { conceptions. In addition, although } \\
\text { some peer-peer interaction is } \\
\text { integrated into the method, the } \\
\text { description of the ILD's does not } \\
\text { emphasize the importance of social } \\
\text { engagement in the learning process. } \\
\text { Therefore we rate ILD's as being } \\
\text { mixed within the learning view } \\
\text { category. }\end{array}$ & $\begin{array}{l}\text { The developers of workshop } \\
\text { physics express clear } \\
\text { constructivist conceptions and } \\
\text { explicitly dismiss } \\
\text { transmission-based } \\
\text { conceptions. Therefore we } \\
\text { rate workshop physics as } \\
\text { alternative within the } \\
\text { learning view category. }\end{array}$ \\
\hline $\begin{array}{l}\text { Instructional } \\
\text { Decisions (P2) }\end{array}$ & $\begin{array}{l}\text { We find no practices consistent } \\
\text { with student autonomy expressed } \\
\text { in the tutorials. In addition, } \\
\text { many of the practices described } \\
\text { were consistent with teacher } \\
\text { control. Therefore we rate the } \\
\text { tutorials as traditional } \\
\text { within the instructional decisions } \\
\text { category. }\end{array}$ & $\begin{array}{l}\text { We find no practices consistent } \\
\text { with student autonomy expressed in } \\
\text { the ILD's. In addition, many of the } \\
\text { practices described were consistent } \\
\text { with teacher control. Therefore we } \\
\text { rate the ILD's as traditional } \\
\text { within the instructional decisions } \\
\text { category. }\end{array}$ & $\begin{array}{l}\text { Although there is some } \\
\text { opportunity for student } \\
\text { autonomy in the workshop } \\
\text { physics environment most of } \\
\text { the course activities are } \\
\text { determined by the teacher. } \\
\text { It is the teacher who decides } \\
\text { content, assessment, and the } \\
\text { larger frame of pace. When } \\
\text { students do have autonomy it } \\
\text { is either optional (individual } \\
\text { projects) or only occasional } \\
\text { (student-designed experiments). } \\
\text { Therefore we rate Workshop } \\
\text { Physics as semitraditional } \\
\text { within the instructional } \\
\text { decisions category. }\end{array}$ \\
\hline
\end{tabular}

might espouse only conceptions on the alternative side of the framework. Additionally, while it is difficult to ascertain the "conceptions" of an entity which cannot be interviewed (such as a curriculum) many guiding philosophies are explicitly described in the curricular documentation and it is possible to make reasonable inferences about others. We argue that these embedded conceptions are more important than the personal conceptions of the developers since they represent how the curriculum will be experienced by potential users.
Tables indicating the details of our placement of each curriculum within each category, including the subcategories, are included in Appendix C. Table IV provides a summary of these placements. Each curriculum is rated on each dimension according to the following scheme: TraditionalPractice or conception is overwhelmingly traditional. Semitraditional-Evidence of some significant alternative practices or conceptions along with predominantly traditional practices or conceptions. Mixed-Significant evidence 
of both traditional and alternative practice or conception. Semialternative-Evidence of significant traditional practices or conceptions along with predominantly alternative practices or conceptions. Alternative-Practice or conception is overwhelmingly alternative.

\section{A. Embraced alternative practice: Interactivity}

An area strongly embraced by PER is the practice of interactivity discussed in the development of the framework section above. The discourse in PER strongly shuns the traditional lecture-based approach characterized by students sitting quietly taking notes in favor of a classroom where students talk to each other, share their ideas and even engage in hands-on activities during class time. Although the three PER-based curricula that we analyzed are all often used as examples of interactive curricula, ${ }^{23,61}$ notice from Table IV and Appendix $\mathrm{C}$ that they actually vary quite substantially on the degree and type of interactivity.

\section{B. Embraced alternative conception: Constructivism}

A strongly embraced conception in PER is the alternative learning view of constructivism. Just as with interactivity, constructivist conceptions abound in both the discourse and practice of the PER community. Also, just as with interactivity, the three PER-based curricula vary significantly on the degree and type of constructivist learning views embraced.

\section{Nonembraced alternative practice: Student autonomy}

Although evidence in the educational research literature points to student autonomy as an instructional practice associated with improved student learning, ${ }^{69}$ this practice has not been widely embraced by PER. All of the curriculum we considered, including the otherwise radical Workshop Physics approach, were mostly or entirely traditional along the autonomy dimension. In fact, PER often removes autonomy over the learning process by strongly directing student behavior.

\section{Discussion}

While it might not be surprising to many readers that PER curricula often embrace interactivity and constructivist learning views, the differences between the three PER curricula in these areas suggest that it is important to clearly articulate these practices and conceptions. This facilitates discussion and comparison within the PER community as well as with those outside the PER community. The framework provides a tool that can be used for such articulation and also allows for distinctions to be made between different curricula.

One possible reason to articulate such distinctions is to compare results. For example, available evidence suggests that interactive practice results in higher learning gains ${ }^{23}$ and that the more interactive the practice, the greater the gain ${ }^{61,70}$ —see Fig. 1. While it may not always be possible to implement the most interactive curricula available, this evidence suggests that both instructors and curricula should attempt to be as interactive as possible given their other constraints.

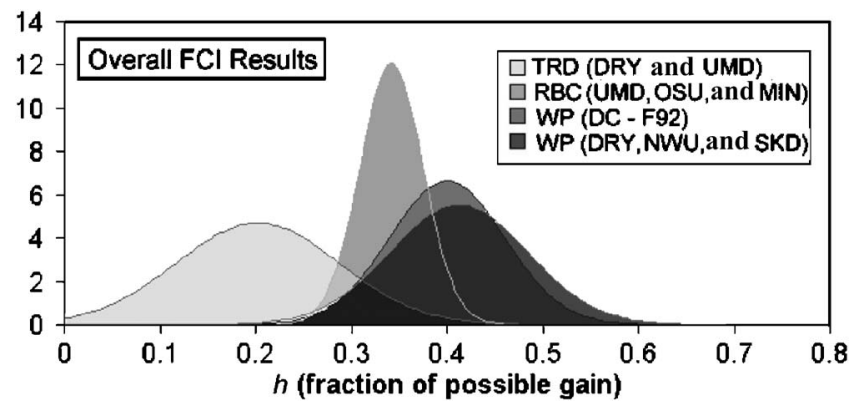

FIG. 1. Force concept inventory (FCI) results from nine schools with varying degrees of interactivity: traditional lecture classes (TRD), lecture classes supplemented with research-based activities (RBC), and Workshop Physics classes (WP). (From Ref. 70, used with permission.)

Another possible use of the framework is to look for potentially fruitful future directions to explore. Since the development of interactivity has proven to be a very successful and important aspect of most PER curricula, it seems prudent to ask what alternative practices the PER community has not embraced. As described earlier, we find that student autonomy is not widely embraced in the PER discourse nor is it a practice evident in the PER curricula that we analyzed.

It is not our intention that this paper be focused on the issue of autonomy. However, having used our framework to illuminate a potential area of interest for the community, we believe it is illustrative to briefly discuss the implications of this finding. Therefore in the following section we will diverge for a moment from our discussion of the framework to argue that there is enough evidence in favor of the benefit of student autonomy to merit serious investigation by the PER community.

\section{E. An argument for the consideration of student autonomy}

According to our analysis of three PER curricula described above, all embody practices which are largely traditional with regard to who makes instructional decisions. There is, of course, nothing intrinsically wrong with being on the traditional side of practice. However, the extent to which practice is traditional or alternative should be an intentional choice. It is worth asking the question, are the goals of PER better supported by teacher control or student autonomy? As Weimer puts it, "Despite our extensive reliance on rules, requirements, and extrinsic motivators, we almost never ask whether these rules-oriented and require-that-you-do-it approaches are having an overall desired effect. We know they seem to work in the short term, but are they creating intellectually mature, responsible, motivated learners?" (Ref. 32, p. 92.)

Consider the goal of helping students become independent learners and thinkers who have the ability and confidence to critically examine ideas. For example, Redish states that "The task of the physics teacher today is to figure out how to help a much larger fraction of the population understand how the world works, how to think logically, and how to evaluate science. This is doubly important in democratic countries where a significant fraction of the adult population 
is involved in [making decisions]." (Ref. 61, p. 7.)

Student autonomy is more consistent with this goal because students need the opportunity to think independently if they are to become independent thinkers. In contrast, teacher control is more consistent with the goals of encouraging respect for authority and teaching discipline. As Karplus stated, "Students get a sense of control and responsibility [when given autonomy] that will encourage them to take more intellectual initiative in their studies and investigations in the future." (Ref. 71, p. 812.)

Although much of the rhetoric of PER is generally consistent with student autonomy, certain conceptions appear to pull most curricula toward teacher control. For example, common conceptions within the PER community are that students cannot effectively learn physics content without sufficient direction. "Well they actually can't do it, the openended things completely overwhelm these students." (PER Researcher No. 1, Ref. 72.) There is also the conception that students must be forced to learn, "If you want students to learn something, you have to test them on it." (Ref. 61, p. 75.) In addition, many argue that students are not capable of deciding what they need to learn-they need an expert to do that for them. "But the students I don't think [should] decide what they need to learn and at what pace, because one, they don't know what they need to know." (PER researcher no. 2 Ref. 72).

Thus in practice, many PER curricula actually reduce the limited autonomy that students typically have under traditional instruction. Faculty that we interviewed voiced concerns about the higher degree of teacher control required by many PER curricula. They had reservations about forcing students to interact with each other, enforcing the use of a specific problem solving framework, or calling on specific students in class. ${ }^{12}$ For example, one instructor stated that he did not require peer to peer interaction as it limits student autonomy. "That is my observation over many years of teaching, yes. That if I try to do it the [suggested way], I think they think they are being forced to do something they don't want to do...I think the different kinds of students want to do things in different ways" (Non-PER Faculty, Ref. 12). We note, however, that while traditional instruction may appear to foster student autonomy, students are typically given only superficial choices. While students may have the opportunity to opt out of participating in class, it is still the teacher who makes all of the important instructional decisions with little or no student input.

Thus it appears that student autonomy is commonly considered to be a practice that, while desirable in theory, is assumed to be not realistic to implement. However, there does not appear to be any research evidence to support this view. On the other hand, there is research-based evidence that not only can students effectively learn when given autonomy, but that their learning is improved. A review of the research on student autonomy indicates that when given choices students work faster, produce higher quality work, remember tasks better, are willing to work for longer periods, take greater pride in their work, are more creative, are more motivated, perform better on standardized tests, and improve their reasoning skills. ${ }^{69}$ In addition, there are a handful of schools that operate primarily around self-directed learning, such as Sudbury Valley, a school with no academic requirements. From a followup study of the graduates of Sudbury, Gray $^{73}$ reports that graduates "have had no apparent difficulty being admitted to or adjusting to the demands of traditional higher education and have been successful in a wide variety of careers. Graduates reported that...the school benefited them by allowing them to develop their own interests and by fostering such traits as personal responsibility, initiative, curiosity, ability to communicate well with people regardless of status, and continued appreciation and practice of democratic values." (Ref. 73, p. 182.)

Given the success PER has found by embracing other alternative practices, the research-based support for student autonomy in other areas, and the obvious contradictions between many goals embraced by PER researchers (e.g., criti$\mathrm{cal}$, independent thinking) and the outcomes of teacher control, it seems reasonable to conduct research to determine what aspects, if any, of student autonomy might be profitably embraced by PER.

We do not believe this to be an easy goal to obtain. A student who has been told what and how to learn for 12 or more years will initially have great difficulty if placed in a strongly autonomous environment. Additionally, most instructors have institutional expectations (i.e., content coverage, inflexible structure of course meeting times) on them that make it difficult to give too much control to the students. However, moving towards instruction that supports student autonomy is possible. Small steps can be made, for example, by de-emphasizing grades as a motivation to learn ${ }^{74}$ or by having students submit questions that they have about their assigned textbook reading rather than administer a reading quiz. ${ }^{75}$ While autonomy may be difficult to integrate, the potential benefits make the effort a worthwhile endeavor.

\section{CONCLUSION}

We have introduced a comprehensive framework that can be used as a tool to articulate and compare the conceptions and practices of individual instructors as well as curricula. We have also shown an example of how this tool can be applied by categorizing PER curricula. We found that three PER curricula have generally embraced the alternative practice of interactivity over the traditional practice of passive students as well as alternative learning views of constructivism over traditional learning views of transmissionism. At the same time these curricula have not embraced the alternative practice of student autonomy over the traditional practice of teacher control although this practice appears to support goals (such as critical thinking) generally held by members of the PER community.

Much of the rhetoric in the physics education community centers on "improving" learning by "changing" instruction often by making the classroom more "interactive" or by focusing on "problem solving skills." But these terms are often used loosely and are ill defined. We offer our framework as a tool that can be used to begin to catalog and articulate many of these ideas. Specifically, the framework serves three important needs. 


\section{A. Document practices and conceptions of individuals and/or curricula}

The framework can be used to identify practices and conceptions present in a particular setting. As shown in this paper, the framework can be used to document practices and conceptions of curricula. In a separate paper we show that the framework has applications for documenting the practices and conceptions of individual instructors. ${ }^{12}$ Additionally, it documents practices and conceptions in a way that both indicates the robustness of the practice or conception and identifies mixed modes.

\section{B. Provide clear definitions}

As mentioned previously, interactivity is one practice that has been strongly incorporated in mainstream PER research and development. Data collected by Hake indicates that "interactive engagement" is associated with higher learning gains. ${ }^{23}$ In his paper he defines interactive engagement as "designed at least in part to promote conceptual understanding through interactive engagement of students in heads-on (always) and hands-on (usually) activities which yield immediate feedback through discussion with peers and/or instructors." (Ref. 23, p. 65.) This definition, however, is somewhat vague and does not address varying degrees of interactivity. As we have shown, our framework, with its detailed subcategories, offers specifics which can be used to more clearly define meanings of general terms such as "interactive."

Further evidence (see Fig. 1) suggests that the "more interactive" the classroom, the greater the learning gain. Therefore it is useful to ask exactly what makes one curriculum more interactive than another. As we have shown, the concept of more interactive can be defined using the framework. For example, while a classroom that incorporates much student-student discourse is interactive, one that also utilizes student-artifact and student directed student-teacher interactions would be "more interactive." Additionally, the framework suggests that more interactive is also achieved by being "less traditional," i.e., less class time spent with only the teacher talking and the students taking notes.

These definitions help to identify specific aspects of a successful curriculum like Workshop Physics that lead to high learning gains. Clearly defining concepts also gives guidance to curriculum developers and instructors on specific aspects to incorporate in their curricular design.

\section{Provide direction for future research and development}

Not all alternative ideas proposed in the education research literature are common in the rhetoric or products of PER. As we showed in the discussion on student autonomy, something which may at first seem unworkable (giving students more control over their learning) may, in fact, be beneficial if properly implemented. Additionally, as we discussed, the abandonment or embracement of a particular idea can be based on conflicting conceptions (for example, that it is important that students become independent thinkers but that the teacher needs to tell students what they need to know). Use of the framework can make these conflicts ex- plicit as a first step towards their possible resolution.

As another example of the use of the productive identification of conflicting ideas, consider the subdimensions under the conceptions category $\mathrm{C} 3$ : knowledge view:

\begin{tabular}{lc}
\hline \hline Knowledge is developed & Knowledge is developed \\
through the scientific method. & $\begin{array}{c}\text { Knough social interaction. } \\
\text { throug }\end{array}$
\end{tabular}

While these two ideas are in opposition to each other, it is a rare instructor who will fall completely on one side or the other. Most people will exhibit a mix of these ideas, perhaps displaying one more prominently than the other depending on the context in which they are embedded at the moment. For example, in his classic book, Aarons discusses the role of logic, reason, hypothesis testing, and observation in the development of scientific knowledge. ${ }^{76}$ But he also repeatedly emphasizes that scientific knowledge is based in social constructions.

“[Galileo's development of the concept of velocity displays] several significant facets of the scientific enterprise: the roles of inductive and deductive reasoning; the fact that scientific concepts are created by deliberate acts of human intelligence and imagination and are not 'objects' discovered accidentally; that choice may be necessary and that there might be room for aesthetic criteria such as elegance and simplicity." (Ref. 76, p. 295.)

Aarons' statements indicated that he would probably agree with both of the above views, with one or the other gaining importance depending on the context to which applied. These views of knowledge, of course, have important implications for instruction. Through a framework offering oppositely articulated constructs we are able to identify such conflicts, which are likely to be productive areas for future work.

The framework presented in this paper can both identify areas of potential development of practice while also identifying conceptions that may hinder or support such development. Discussions of desired outcomes, new practices towards the achievement of these outcomes, and the identification and articulation of conflicting conceptions regarding these outcomes are healthy and beneficial.

\section{ACKNOWLEDGMENTS}

The authors wish to thank the interviewees who graciously shared their experiences with us as well as Noah Finkelstein and three anonymous reviewers for their helpful comments on earlier versions of this manuscript.

\section{APPENDIX A: INSTRUCTIONAL PRACTICES}

Note: References are not intended to provide complete documentation for each idea, but rather a suggested starting point for those readers interested in reading more about a particular belief or practice. See Table V below for instructional practices. 
TABLE V. Practice categories of the framework.

\begin{tabular}{|c|c|c|}
\hline \multicolumn{3}{|c|}{ Instructional practices } \\
\hline Category label & Generally traditional practices & Generally alternative practices \\
\hline $\mathrm{P} 1$ & Minimal degree of interactivity & Significant degree of interactivity (Ref. 23) \\
\hline A & $\begin{array}{c}\text { Teacher does most of the talking. Few students talk } \\
\text { (lecture) }\end{array}$ & $\begin{array}{l}\text { Students and teacher share talking. Most students talk } \\
\text { (conversation) }\end{array}$ \\
\hline $\mathrm{B}$ & Most discourse is teacher-student & Significant student-student discourse \\
\hline $\mathrm{C}$ & $\begin{array}{c}\text { Discourse focuses on teacher's ideas (e.g., students ask } \\
\text { clarifying questions and teacher asks rhetorical and/or } \\
\text { closed questions) }\end{array}$ & $\begin{array}{c}\text { Discourse focuses on students' ideas (e.g., students and } \\
\text { teacher ask and answer conceptual and/or open-ended } \\
\text { questions) }\end{array}$ \\
\hline $\mathrm{D}$ & Students write teacher's ideas (i.e., take notes) & Students write their own ideas \\
\hline $\mathrm{E}$ & Students are physically passive & $\begin{array}{c}\text { Students are physically active (e.g., interacting with } \\
\text { equipment or materials) }\end{array}$ \\
\hline $\mathrm{P} 2$ & Teacher control (teacher makes all instructional decisions) & $\begin{array}{l}\text { Student autonomy (students have input in instructional } \\
\text { decisions) (Ref. 30) }\end{array}$ \\
\hline A & Teacher decides on content and depth of course & $\begin{array}{c}\text { Students influence content and depth of course (e.g., } \\
\text { individual projects, significant changes in plans based on } \\
\text { questions/interests of students during course) }\end{array}$ \\
\hline $\mathrm{B}$ & $\begin{array}{l}\text { Teacher decides how class time will be spent (e.g., } \\
\text { lecturing or other highly structured activities and labs) }\end{array}$ & $\begin{array}{l}\text { Students decide what they will do in class (e.g., student } \\
\text { designed-activities and labs, centers) }\end{array}$ \\
\hline $\mathrm{C}$ & Teacher decides when and how students will be assessed & $\begin{array}{l}\text { Students have choice over types and/or timing of } \\
\text { assessment }\end{array}$ \\
\hline $\mathrm{D}$ & $\begin{array}{c}\text { Teacher decides what knowledge is valued (e.g., students } \\
\text { expected to learn and use physicists' terms, definitions, } \\
\text { conventions, etc.) }\end{array}$ & $\begin{array}{l}\text { Community knowledge is valued (e.g., students develop } \\
\text { own language to discuss ideas, students share experiences } \\
\text { and perspectives with goal of learning from one another) }\end{array}$ \\
\hline $\mathrm{E}$ & $\begin{array}{l}\text { Class structure decided by teacher and/or school (e.g., } \\
\text { bolted down chairs and tables, length of class and } \\
\text { semester, class size, etc.) }\end{array}$ & $\begin{array}{c}\text { Student have choice in class structure (e.g., flexible room } \\
\text { arrangement, independent study courses) }\end{array}$ \\
\hline $\mathrm{P} 3$ & Knowledge transmission & Knowledge development-inquiry (Ref. 31) \\
\hline A & Students receive explanations and facts & Students develop explanations and models \\
\hline $\mathrm{B}$ & Teacher poses problems and questions to be answered & Students pose problems and questions to be answered \\
\hline $\mathrm{C}$ & Students expected to use scientists language & Students' own words valued \\
\hline $\mathrm{D}$ & Teacher structures experiments & Students design experiments \\
\hline $\mathrm{P} 4$ & Fixed expectations of students & Adjustable expectations of students (Ref.32) \\
\hline A & Success defined by set standards & Success defined by individual improvement \\
\hline $\mathrm{B}$ & Same instruction for all students & $\begin{array}{l}\text { Attempt to meet the different learning needs of all } \\
\text { students }\end{array}$ \\
\hline P5 & Competitive/individualist learning modes & Cooperative learning modes (Ref. 33) \\
\hline A & Grading on a curve & Explicitly encourage students to work together \\
\hline $\mathrm{B}$ & Make only individual assignments & Graded group assignments \\
\hline
\end{tabular}


TABLE V. (Continued.)

\begin{tabular}{|c|c|c|}
\hline \multicolumn{3}{|c|}{ Instructional practices } \\
\hline Category label & Generally traditional practices & Generally alternative practices \\
\hline P6 & External motivators & Internal motivators (Ref. 34) \\
\hline A & $\begin{array}{c}\text { Grades and testing for evaluation (to sort, rank } \\
\text { or certify) }\end{array}$ & Assessment for feedback \\
\hline $\mathrm{B}$ & & Link course to interest/needs of students \\
\hline $\mathrm{P} 7$ & Knowledge-based assessment & Process-based assessment (Ref. 35) \\
\hline A & Timed evaluations & Untimed evaluations \\
\hline $\mathrm{B}$ & Prime value on right answer & Prime value on right process \\
\hline $\mathrm{C}$ & Familiar problems and questions on exams & New problems and questions on exams \\
\hline $\mathrm{D}$ & Derivations & Open-ended questions and problems \\
\hline $\mathrm{E}$ & Test for factual recall & Test for conceptual understanding \\
\hline P8 & Knowledge-based content & Broad content (Ref. 36) \\
\hline A & Explicitly teach only physics facts and principles & $\begin{array}{l}\text { Explicitly teach learning, thinking, and PS skills in } \\
\text { addition to physics content }\end{array}$ \\
\hline $\mathrm{B}$ & Focus on derivations and formulas & Focus on conceptual understanding \\
\hline $\mathrm{C}$ & & Explicitly address epistemological and attitudinal issues \\
\hline $\mathrm{D}$ & & $\begin{array}{l}\text { Explicitly connect course to other disciplines and social } \\
\text { issues }\end{array}$ \\
\hline P9 & Knowledge-driven instructional design & Student-driven instructional design (Ref. 32) \\
\hline A & Emphasis on accuracy of teacher presentation & Emphasis on student comprehension \\
\hline $\mathrm{B}$ & $\begin{array}{l}\text { Lesson progression is basically fixed in advance (e.g., } \\
\text { based on instructor's notes) }\end{array}$ & $\begin{array}{l}\text { Lesson progression is adjustable and shaped by student } \\
\text { questions and comments }\end{array}$ \\
\hline $\mathrm{C}$ & $\begin{array}{l}\text { Pedagogy is based on understanding of the structure of } \\
\text { the physics content }\end{array}$ & Pedagogy is based on understanding of students \\
\hline $\mathrm{D}$ & & $\begin{array}{l}\text { Instructor gathers classroom assessment data (e.g., } \\
\text { student opinion, test performance, FCI scores, etc.) } \\
\text { and uses this to shape instruction }\end{array}$ \\
\hline $\mathrm{P} 10$ & Traditional problem solving & Alternative problem solving (Refs. 37,38) \\
\hline A & $\begin{array}{l}\text { Formulaic problem solving (problems with known } \\
\text { solutions that the problem solver has seen before or are } \\
\text { similar) }\end{array}$ & $\begin{array}{l}\text { Creative problemsolving (problems with known solutions } \\
\text { novel to problem solver, problems with unknown or } \\
\text { open-ended solutions) }\end{array}$ \\
\hline $\mathrm{B}$ & $\begin{array}{c}\text { Solution requires only small pieces of knowledge and is } \\
\text { often based on idealizations }\end{array}$ & $\begin{array}{l}\text { Solution requires combining knowledge from several } \\
\text { areas }\end{array}$ \\
\hline $\mathrm{C}$ & Problems have little application to the life of the solver & Problems are related to the life of the solver \\
\hline $\mathrm{D}$ & $\begin{array}{l}\text { Well-defined problems that only provide information } \\
\text { necessary for the solution }\end{array}$ & Ill-defined problems or problems with excess information \\
\hline $\mathrm{E}$ & Solutions expected to include a correct numerical answer & $\begin{array}{l}\text { Solutions expected to include explanation, prediction } \\
\text { and/or application }\end{array}$ \\
\hline
\end{tabular}


TABLE VI. Conception categories of the framework.

\begin{tabular}{|c|c|c|}
\hline & \multicolumn{2}{|c|}{ Instructional conceptions } \\
\hline & Conceptions consistent with traditional practices & Conceptions consistent with alternative practices \\
\hline $\mathrm{C} 1$ & Traditional learning views & Alternative learning views (Ref. 55) \\
\hline A & $\begin{array}{c}\text { Students receive knowledge from teacher or textbook- } \\
\text { transmissionist }\end{array}$ & $\begin{array}{l}\text { Learners construct knowledge based on prior knowledge- } \\
\text { constructivist }\end{array}$ \\
\hline B & Mentally passive students & Mentally active students \\
\hline $\mathrm{C}$ & Learning is primarily an individual activity & Learning is a social activity (Ref. 77) \\
\hline $\mathrm{D}$ & Learning is primarily a rational activity & Learning is an emotional activity (Ref. 78,79 ) \\
\hline $\mathrm{C} 2$ & Expertise is accomplished by accumulation & $\begin{array}{c}\text { Expertise is accomplished by qualitative changes in } \\
\text { thinking (Ref. 80) }\end{array}$ \\
\hline A & Understanding is measured by factual recall & $\begin{array}{l}\text { Understanding is measured by ability to explain or chose } \\
\text { correct approach }\end{array}$ \\
\hline $\mathrm{B}$ & $\begin{array}{l}\text { Understanding is measured by ability to apply ideas } \\
\text { quickly and accurately to familiar problems or situations }\end{array}$ & $\begin{array}{l}\text { Understanding is measured by ability to apply ideas to } \\
\text { new problems or situations }\end{array}$ \\
\hline $\mathrm{C} 3$ & Positivist knowledge views & Post-positivist knowledge views (Ref. 56) \\
\hline A & Knowledge is objective & Knowledge is culturally bound \\
\hline $\mathrm{B}$ & Knowledge is developed through the scientific method & Knowledge is developed through social interaction \\
\hline $\mathrm{C}$ & School passes along knowledge & School socializes in knowledge development \\
\hline $\mathrm{D}$ & Knowledge resides in experts & Knowledge resides in communities \\
\hline $\mathrm{C} 4$ & Introductory physics is a quantitative discipline & Introductory physics is a broad discipline (Ref. 57) \\
\hline A & Doing physics means solving mathematical problems & $\begin{array}{c}\text { Doing physics involves a variety of things, including } \\
\text { solving conceptual problems }\end{array}$ \\
\hline $\mathrm{C} 5$ & $\begin{array}{c}\text { Role of schooling and physics education is to sort and } \\
\text { certify students }\end{array}$ & $\begin{array}{c}\text { Role of schooling and physics education is to develop } \\
\text { individual thinkers (Ref. 58) }\end{array}$ \\
\hline A & $\begin{array}{c}\text { Selection process (sort students for economic and social } \\
\text { roles) }\end{array}$ & All students should be allowed to succeed \\
\hline $\mathrm{B}$ & $\begin{array}{l}\text { Certification process (grades certify that students have } \\
\text { certain skills) }\end{array}$ & $\begin{array}{l}\text { Grades should be feedback for student only and used for } \\
\text { self-improvement }\end{array}$ \\
\hline $\mathrm{C}$ & $\begin{array}{l}\text { School should teach students to follow directions, respect } \\
\text { authority, and obey rules }\end{array}$ & $\begin{array}{l}\text { School should teach students tobecome independent, } \\
\text { creative, and critical thinkers who can question authority }\end{array}$ \\
\hline $\mathrm{D}$ & $\begin{array}{l}\text { School should teach skills that are only focused on } \\
\text { students' professional lives }\end{array}$ & $\begin{array}{l}\text { School should teach skills that make students' personal } \\
\text { lives richer }\end{array}$ \\
\hline C6 & Beliefs about students: traditional & Beliefs about students: alternative (Ref. 59) \\
\hline A & All students can learn using the same methods & Students think and learn differently, have different needs \\
\hline B & Only some students are capable of learning physics & All students can learn physics \\
\hline $\mathrm{C}$ & Students must be forced to learn physics & Students want to learn physics \\
\hline $\mathrm{D}$ & $\begin{array}{l}\text { Students are best motivated externally by grades/ } \\
\text { punishments }\end{array}$ & $\begin{array}{l}\text { Students are best motivated intrinsically (make learning } \\
\text { meaningful, connected to student's lives) }\end{array}$ \\
\hline $\mathrm{E}$ & $\begin{array}{l}\text { Students cannot make good decisions about their learning } \\
\text { needs }\end{array}$ & Students can make decisions about their learning needs \\
\hline
\end{tabular}


TABLE VI. (Continued.)

\begin{tabular}{|c|c|c|}
\hline & Instruct & ceptions \\
\hline & Conceptions consistent with traditional practices & Conceptions consistent with alternative practices \\
\hline $\mathrm{C} 7$ & Role of the teacher: teacher should teach & Role of the teacher: teacher should guide (Ref. 32) \\
\hline A & Determine what and how students should learn & $\begin{array}{l}\text { Provide a resource to students as they decide what to } \\
\text { learn and at what pace }\end{array}$ \\
\hline $\mathrm{B}$ & Determine the pace of the class & Lead discussions among students \\
\hline $\mathrm{C}$ & Present knowledge, be an expert & Develop situations where students can learn \\
\hline $\mathrm{D}$ & Judge students performance & Provide feedback \\
\hline $\mathrm{E}$ & & Motivate students \\
\hline $\mathrm{C} 8$ & Views on diversity: diversity is a nuisance & Views on diversity: diversity is a resource (Ref. 60) \\
\hline A & $\begin{array}{l}\text { A nonhomogeneous class is a nuisance because the } \\
\text { students aren't all the same }\end{array}$ & $\begin{array}{l}\text { A nonhomogeneous class is a resource because different } \\
\text { students bring different perspectives }\end{array}$ \\
\hline $\mathrm{B}$ & Only the "good" students are valued & All students are valued \\
\hline $\mathrm{C}$ & $\begin{array}{l}\text { Students should adapt to the teacher, failure is the fault } \\
\text { of the student alone }\end{array}$ & $\begin{array}{c}\text { Teachers should adapt to the students, both teachers and } \\
\text { students are responsible for failure }\end{array}$ \\
\hline C9 & Content outcomes of physics education & Process outcomes of physics education (Ref. 61) \\
\hline $\mathrm{A}$ & To expose students to facts, concepts of physics & To develop an understanding of physics concepts \\
\hline $\mathrm{B}$ & $\begin{array}{l}\text { Students should be able to quickly and accurately solve } \\
\text { familiar problems }\end{array}$ & $\begin{array}{l}\text { Students should be able to apply physics ideas to new } \\
\text { situations }\end{array}$ \\
\hline $\mathrm{C}$ & & $\begin{array}{c}\text { Students should develop thinking, learning, and } \\
\text { problem-solving skills }\end{array}$ \\
\hline $\mathrm{C} 10$ & Traditional views of scientific literacy & Alternative views of scientific literacy (Ref. 7) \\
\hline A & Develop an appreciation for science & Develop ability and confidence to critique science \\
\hline $\mathrm{B}$ & $\begin{array}{l}\text { Develop respect for objectivity found in the scientific } \\
\text { method }\end{array}$ & $\begin{array}{c}\text { Understand how "scientific knowledge" is influenced by } \\
\text { culture and society }\end{array}$ \\
\hline $\mathrm{C}$ & $\begin{array}{l}\text { Informed citizen who understands scientists' science and } \\
\text { can use it in decision making }\end{array}$ & $\begin{array}{c}\text { Informed citizen who can produce science to improve } \\
\text { their world }\end{array}$ \\
\hline $\mathrm{D}$ & Individual based & Community based \\
\hline
\end{tabular}

\section{APPENDIX B: INSTRUCTIONAL CONCEPTIONS}

See Table VI for instructional conceptions.

\section{APPENDIX C: SUPPLEMENTARY AUXILIARY MATERIAL}

Analysis of curricula along the interactivity category.

See separate auxiliary material for tables indicating the details of our placement of each curriculum within each category, including the subcategories.

${ }^{1}$ L. C. McDermott and E. F. Redish, Resource letter: PER-1: Physics education research, Am. J. Phys. 67, 755 (1999).

${ }^{2}$ Exemplified by Refs. 1-140 from the McDermott-Redish resource letter (Ref. 1).

${ }^{3}$ Exemplified by Refs. 141-152 from the McDermott-Redish resource letter (Ref. 1).
${ }^{4}$ Exemplified by Refs. $163-173$ from the McDermott-Redish resource letter (Ref. 1).

${ }^{5}$ R. Ehrlich, Where are the physics majors?, Am. J. Phys. 66, 79 (1998).

${ }^{6}$ N. Finkelstein, Teaching and learning physics: A model for coordinating physics instruction, outreach, and research, J. Scholar- 
ship Teach. Learn. 4, 1 (2004).

${ }^{7}$ W.-M. Roth and A. C. Barton, Rethinking Scientific Literacy (Routledge, New York, 2004).

${ }^{8}$ E. Mazur, Peer Instruction: A User's Manual (Prentice-Hall, Upper Saddle River, NJ, 1997).

${ }^{9}$ Y. Bertrand, Contemporary Theories and Practice in Education (Atwood Publishing, Madison, WI, 2003).

${ }^{10} \mathrm{C}$. Henderson and M. Dancy, When one instructor's interactive classroom activity is another's lecture: Communication difficulties between faculty and educational researchers, paper presented at the American Association of Physics Teachers Winter Meeting, Albuquerque, NM, 2005, http://homepages.wmich.edu/ $\sim$ chenders/Publications/Publications.htm

${ }^{11} \mathrm{C}$. Henderson and M. Dancy, Physics faculty and educational researchers: Divergent expectations as barriers to the diffusion of innovations (to be published), http://homepages.wmich.edu/ $\sim$ chenders/Publications/Publications.htm

${ }^{12}$ C. Henderson and M. Dancy, Barriers to the use of researchbased instructional strategies: The dual role of individual and situational characteristics (to be published), http:// homepages.wmich.edu/ chenders/Publications/Publications.htm

${ }^{13}$ P. E. Adams and G. H. Krockover, Stimulating constructivist teaching styles through use of an observation rubric, J. Res. Sci. Teach. 36, 955 (1999), http://dx.doi.org/10.1002/(SICI)10982736(199910)36:8<955::AID-TEA4>3.0.CO;2-3

${ }^{14}$ A. F. Artzt and E. Armour-Thomas, A cognitive model for examining teachers' instructional practices in mathematics: A guide for facilitating teacher reflection, Educ. Stud. Math. 40, 211 (1999).

${ }^{15} \mathrm{M}$. Ingle and S. Cory, Classroom implementation of the national science education standards: A snapshot instrument to provide feedback and reflection for teachers, Sci. Educator 8, 49 (1999).

${ }^{16} \mathrm{~B}$. Johnson and R. McClure, Validity and reliability of a shortened, revised version of the constructivist learning environment survey (CLES), Learning Environ. Res. 7, 65 (2004).

${ }^{17}$ J. A. Luft, Assessing science teachers as they implement inquiry lessons: The extended inquiry observational rubric, Sci. Educator 36, 141 (1999).

${ }^{18}$ J. A. Luft, Changing inquiry practices and beliefs: The impact of an inquiry-based professional development program on beginning and experienced secondary science teachers, Int. J. Sci. Educ. 23, 517 (2001).

${ }^{19}$ D. MacIsaac and K. Falconer, Reforming physics instruction via rtop, Phys. Teach. 40, 479 (2002), http://link.aip.org/link/?PTE/ 40/479/1

${ }^{20}$ D. Sawada, M. D. Piburn, E. Judson, J. Turley, K. Falconer, R. Benford, and I. Bloom, Measuring reform practices in science and mathematics classrooms: The reformed teaching observation protocol, Sch. Sci. Math. 102, 245 (2002).

${ }^{21}$ P. E. Simmons, A. Emory, T. Carter, T. Coker, B. Finnegan, D. Crockett, L. Richardson, R. Yager, J. Craven, J. Tillotson, H. Brunkhorst, M. Twiest, K. Hossain, J. Gallagher, D. DugganHaas, J. Parker, F. Cajas, Q. Alshannag, S. McGlamery, J. Krockover, P. Adams, B. Spector, T. LaPorta, B. James, K. Rearden, and K. Labuda, Beginning teachers: Beliefs and classroom actions, J. Res. Sci. Teach. 36, 930 (1999).

${ }^{22}$ R. B. Barr and J. Tagg, From teaching to learning-A new paradigm for undergraduate education, Change 27 (6), 13 (1995).

${ }^{23}$ R. R. Hake, Interactive-engagement vs. Traditional methods: A six-thousand-student survey of mechanics test data for introduc- tory physics courses, Am. J. Phys. 66, 64 (1998).

${ }^{24}$ D. E. Meltzer and K. Manivannan, Transforming the lecture-hall environment: The fully interactive physics lecture, Am. J. Phys. 70, 639 (2002).

${ }^{25} \mathrm{P}$. Heller, R. Keith, and S. Anderson, Teaching problem solving through cooperative grouping. Part 1: Groups versus individual problem solving, Am. J. Phys. 60, 627 (1992).

${ }^{26}$ A. Van Heuvelen, Overview, case study physics, Am. J. Phys. 59, 898 (1991)

${ }^{27}$ C. J. Hieggelke, D. P. Maloney, S. E. Kanim, and T. L. O'Kuma, E\&M tipers: Electricity and Magnetism Tasks Inspired by Physics Education Research (Prentice-Hall, Upper Saddle River, NJ, 2006).

${ }^{28}$ W. Christian and M. Belloni, Physlets: Teaching Physics with Interactive Curricular Material (Prentice-Hall, Upper Saddle River, NJ, 2001).

${ }^{29}$ L. T. Escalada and D. A. Zollman, An investigation on the effects of using interactive digital video in a physics classroom on student learning and attitudes, J. Res. Sci. Teach. 34, 467 (1998).

${ }^{30}$ A. S. Neill, The New Summerhill (Penguin Books, London, 1992).

${ }^{31}$ National Research Council, Inquiry and the National Science Education Standards: A Guide for Teaching and Learning (The National Academies Press, Washington, DC, 2000).

${ }^{32}$ M. Weimer, Learner-Centered Teaching: Five Key Changes to Practice (Jossey-Bass, San Francisco, 2002).

${ }^{33}$ D. W. Johnson, R. T. Johnson, and K. A. Smith, Active Learning: Cooperation in the College Classroom (Interaction Book Company, Edina, MN, 1991).

${ }^{34} \mathrm{~S}$. Graham and B. Weiner, Theories and principles of motivation, in Handbook of Educational Psychology, edited by D. C. Berliner and R. C. Calfee (MacMillan, New York, 1996).

${ }^{35}$ P. Black and D. William, Inside the black box: Raising standards through classroom assessment, Phi Delta Kappan 80, 139 (1998). www.pdkint1.org/kappan/kb1a9810.htm

${ }^{36}$ A. Elby, Helping physics students learn how to learn, Am. J. Phys. 69, 554 (2001).

${ }^{37} \mathrm{P}$. Heller and M. Hollabaugh, Teaching problem solving through cooperative grouping. Part 2: Designing problems and structuring groups, Am. J. Phys. 60, 637 (1992).

${ }^{38} \mathrm{~S}$. Mahajan, Estimating gas mileage: An example of orderof-magnitude physics, http://www.citebase.org/abstract?id = oai:arXiv.org:physics/0512209

${ }^{39}$ A. G. Thompson, Teachers' beliefs and conceptions: A synthesis of the research, in Handbook of Research on Mathematics Teaching and Learning, edited by D. A. Grouws (MacMillan, New York, 1992).

${ }^{40}$ J. Calderhead, Teachers: Beliefs and knowledge," in Handbook of Educational Psychology, edited by D. C. Berliner and R. C. Calfee (Prentice-Hall, New York, 1996).

${ }^{41}$ R. Kane, S. Sandretto, and C. Heath, Telling half the story: A critical review of research on the teaching beliefs and practices of university academics, Rev. Educ. Res. 72, 177 (2002).

${ }^{42} \mathrm{~K}$. Murray and R. Macdonald, The disjunction between lecturers' conceptions of teaching and their claimed educational practice, J. Higher Educ. 33, 331 (1997),

${ }^{43}$ L. Norton, J. T. E. Richardson, J. Hartley, S. Newstead, and J. Mayes, Teachers' beliefs and intentions concerning teaching in higher education, J. Higher Educ. 50, 537 (2005).

${ }^{44}$ O. Lantz and H. Katz, Chemistry teachers' functional paradigms, Sci. Educ. 71, 117 (1987). 
${ }^{45} \mathrm{~J}$. Nespor, The role of beliefs in the practice of teaching, J. Curric. Stud. 19, 317 (1987).

${ }^{46}$ S. M. Wilson, L. S. Shulman, and A. E. Richert, 150 different ways of knowing: Representations of knowledge in teaching, in Exploring Teachers' Thinking, edited by J. Calderhead (Cassell Educational Limited, London, 1987).

${ }^{47}$ M. F. Pajares, Teachers' beliefs and educational research: Cleaning up a messy construct, Rev. Educ. Res. 62, 307 (1992).

${ }^{48} \mathrm{M}$. Dancy and C. Henderson, Beyond the individual instructor: Systemic constraints in the implementation of research-informed practices, in Proceedings (peer reviewed) of the 2004 AAPT Physics Education Research Conference, edited by Scott Franklin, Jeff Marx, and Paula Heron (American Institute of Physics, Melville, NY, 2005), http://homepages.wmich.edu/ chenders/ Publications/PERC2004Dancy.pdf

${ }^{49} \mathrm{M}$. Prosser and K. Trigwell, Understanding Learning and Teaching: The Experience in Higher Education (St. Edmundsbury Press, St. Edmunds, Great Britain, 1999).

${ }^{50}$ D. W. Sunal, J. Hodges, C. S. Sunal, K. W. Whitaker, L. M. Freeman, L. Edwards, R. A. Johnston, and M. Odell, Teaching science in higher education: Faculty professional development and barriers to change, Sch. Sci. Math. 101, 246 (2001).

${ }^{51}$ D. S. Kenkel, What you don't know really won't hurt you, J. Policy Anal. Manage. 10 (2), 304 (1991).

${ }^{52}$ K. Kobus, Peers and adolescent smoking, Addiction 98, 37 (2003).

${ }^{53}$ M. J. Jarvis, Why people smoke, BMJ 328, 277 (2004).

${ }^{54}$ J. G. Knowles and D. Holt-Reynolds, Shaping pedagogies through personal histories in preservice teacher education, Teach. Coll. Rec. 91, 87 (1991).

${ }^{55}$ National Research Council, How People Learn: Brain, Mind, Experience, and School (National Academy Press, Washington, DC, 1999).

${ }^{56}$ P. C. Taylor, P. Gilmer, and K. Tobin, Transforming Undergraduate Science Teaching: Social Constructivist Perspectives (Peter Lang, New York, 2002).

${ }^{57}$ A. Van Heuvelen, Learning to think like a physicist: A review of research-based instructional strategies, Am. J. Phys. 59, 891 (1991).

${ }^{58} \mathrm{P}$. Freire, Pedagogy of the Oppressed (Continuum International Publishing Group, New York, 2000).

${ }^{59}$ A. Kohn, What to Look for in a Classroom... and Other Essays (Jossey-Bass, San Francisco, 1998).

${ }^{60}$ A. Barton, J. Ermer, T. Burkett, and M. Osborne, Teaching Science for Social Justice (Teachers College Press, New York, 2003).

${ }^{61}$ E. F. Redish, Teaching Physics with the Physics Suite (John Wiley \& Sons, Hoboken, NJ, 2003).
${ }^{62}$ E. Yerushalmi, C. Henderson, K. Heller, P. Heller, and V. Kuo, Physics faculty beliefs and values about the teaching and learning of problem solving. Part I: Mapping the common core, Phys. Rev. ST Phys. Educ. Res. (to be published).

${ }^{63}$ E. T. Pascarella and P. T. Terenzini, From How college affects students, in Teaching and Learning in the College Classroom, edited by Kenneth A. Feldman, and Michael B. Paulsen (Simon \& Schuster, Needham Heights, MA, 1994).

${ }^{64}$ L. McDermott and P. S. Shaffer, Tutorials in Introductory Physics (Prentice-Hall, Upper Saddle River, NJ, 2002).

${ }^{65}$ L. McDermott, P. S. Shaffer, and the Physics Education Group, Instructors Guide: Tutorials in Introductory Physics (PrenticeHall, Upper Saddle River, NJ, 2003).

${ }^{66}$ D. R. Sokoloff and R. K. Thornton, Using interactive lecture demonstrations to create an active learning environment, Phys. Teach. 35, 340 (1997).

${ }^{67}$ P. W. Laws, Calculus-based physics without lectures, Phys. Today 44 (12), 24 (1991).

${ }^{68}$ P. W. Laws, Workshop Physics Activity Guide (John Wiley \& Sons, New York, 1997).

${ }^{69}$ A. Kohn, Choices for children: Why and how to let students decide, Phi Delta Kappan 75, 8 (1993).

${ }^{70}$ J. M. Saul and E. F. Redish, Final evaluation report for FIPSE grant \#p116p50026: Evaluation of the workshop physics dissemination project (College Park, University of Maryland, 1997), http://www.physics.ucf.edu/ saul/articles/WP-FIPSE_Rprt.pdf

${ }^{71}$ R. Karplus, Response by the oersted medalist: Autonomy and input, Am. J. Phys. 49, 811 (1981).

${ }^{72}$ These interviews with PER researchers were conducted by the authors as part of a separate study.

${ }^{73}$ P. Gray and D. Chanoff, Democratic schooling: What happens to young people who have charge of their own education?, Am. J. Educ. 94, 182 (1986).

${ }^{74}$ M. Dancy, Questioning assumptions: Why do we grade?, Paper presented at the American Association of Physics Teachers Winter Meeting, Miami, FL, 2004.

${ }^{75}$ C. Henderson and A. Rosenthal, Reading questions: Encouraging students to read the text before coming to class, J. Coll. Sci. Teach. 35, 46 (2006).

${ }^{76}$ A. B. Arons, A Guide to Introductory Physics Teaching (Wiley, New York, 1990).

${ }^{77}$ D. W. Johnson and R. T. Johnson, Cooperation and Competition: Theory and Research (Interaction Book Co., Edina, MN, 1989).

${ }^{78} \mathrm{~S}$. Tobias, They're not Dumb, They're Different: Stalking the Second Tier (Research Corporation, Tucson, AZ, 1990).

${ }^{79}$ K. O'Regan, Emotion and e-learning, Asynchronous Learn. Networks 7, 78 (2003), http://www.sloan-c.org/publications/jaln/ v7n3/v7n3_oregan.asp

${ }^{80}$ C. Bereiter and M. Scardamalia, Surpassing Ourselves: An Inquiry into the Nature and Implications of Expertise (Open Court Publishing, Peru, IL, 1993). 